\title{
THE EFFECT OF THE HEAT FLOW AMOUNT AND CONTINUITY ON DRIED RICE QUALITY
}

\author{
Filip Mojsovski, Dame Dimitrovski \\ Faculty of Mechanical Engineering, "Ss. Cyril and Methodius" University in Skopje, \\ P.O. Box 464, MK-1001 Skopje, Republic of North Macedonia \\ filip.mojsovski@mf.edu.mk
}

\begin{abstract}
A b s t r a c t: A research was conducted through field tests on mixed-flow rice dryer. The realization of the planned study was carried out by applying intermittent system of drying and selection of correct drying conditions. The heat flow amount and continuity were observed and evaluated in multi-thermal zoned drying process. Hot air temperatures, up to $45^{\circ} \mathrm{C}$, were used. Paddy from local rice varieties, with the initial moisture content, wet basis, up to $26 \%$, was processed to the desirable final moisture content, from $8 \%$ to $12 \%$. Reached at three levels, the final moisture content depends on intended rice use: 1) for sale, 2) for one year storage and 3) for five years storage. The effect of drying air temperature level, heat flow intensity and retention time duration on dried paddy quality was analyzed.
\end{abstract}

Key words: drying; mixed-flow dryer; intermittent drying; paddy

\section{ВЛИЈАНИЕ НА ИНТЕНЗИТЕТОТ И КОНТИНУИТЕТОТ НА ТОПЛИНСКИОТ ТЕК ВРЗ КВАЛИТЕТОТ НА СУШЕН ОРИЗ}

\begin{abstract}
А п с т р а к т: Спроведено е теренско истражување на сушилница за ориз со мешан проток. Планираната студија е реализирана со примена на сушење со прекини и со избор на правилни услови на сушење. Интензитетот и континуитетот на топлинскиот тек беа следени и оценувани во повеќезонски процес на сушење. Употребувана е температурата на топол воздух до $45^{\circ}$ С. Оризовата арпа од локални сорти е сушена од почетната содржина на влага, основна, поголема од $26 \%$, до саканата крајна содржина на влага од 8 до 12 \%. Крајната содржина на влага е постигната на три нивоа, во зависност од планираната употреба на сушениот производ: 1) за продажба, 2) за едногодишно складирање и 3) за петгодишно складирање. Анализирано е влијанието на нивото на температурата на воздухот за сушење, интензитетот на топлинскиот тек и времето на ретенција врз квалитетот на сушената оризова арпа.
\end{abstract}

Клучни зборови: сушење; сушилница со мешан проток; сушење со прекини; оризова арпа

\section{INTRODUCTION}

The amount and the continuity of heat flow received in dried rice is of primary importance for the quality of processed food.

The operational conditions in rice dryer are different, compared to those for other cereals. Rice is sensitive to the level of drying temperature. To avoid the kernel breakage during drying, the permitted paddy temperature must be respected. Rice, unlike corn and wheat, can't be dried in high tempera- ture drying systems. Of all cereals, rice is probably most difficult to process without quality loss [1].

Mixed-flow dryers enable rice to be dried uniformly and the grain is usually with a higher quality than the one dried in other models.

Rice quality depends on its physical and chemical characteristics. Head yield, color and cooking quality are quoted as quality characteristics of rice, that need to be maintained during the drying process $[2,3]$. However, consumers estimate rice quality differently [4]. Inspections of grain are based on 
national standards. In the United States of America rough rice is arranged in six classes [5].

The realization of the planned research was conducted in three steps: 1) correction of the dryer construction, 2) applying intermittent system of drying, and 3) selection of correct drying conditions.

Drying is the process of simultaneous heat and mass transfer, carried out in two stages: 1) water passes in gas state, and 2) water vapor is taken away from the dried product. The heat transferred from the air to the dried rice is used for heating of the grain kernels, for evaporating water from the kernels, and for heating of the water vapor evaporated from the kernels. The process of energy transfer needs time. The incorrect intensity of involving heat flow in the drying room can produce negative effects.

In order to have the possibility of heat flow regulation, intermittent drying process is used. The drying process is interrupted by inserting tempering section, which separates two adjoining drying stages. During the period of tempering the grain is not subjected to an air treatment, and thus the temperature and moisture gradients within the individual grain kernels are diminished before drying is resumed. Tempering allows moisture within the kernel to be redistributed, to eliminate the gradient [6, $7,8]$. The length of tempering zone results in retention time of partially dried grain. The period is adequate to sufficiently reduce the temperature and moisture in the kernels.

The relevant parameters for multi-thermal zone drying with tempering are rarely published. The purpose of this paper is to present relevant data for paddy drying in mixed-flow dryer, obtained with conducted research on a industrial type dryer. The attention is concentrated on rice, because of its significance for local agriculture. Although the production was reduced in the last decade, rice is still important crop in local cereals production. The maximum cultivated area of 10000 ha reached in the past, is now decreased for two times [9].

\section{EXPERIMENTAL}

A mixed-flow grain dryer is shown in Figure 1. The dryer is composed of six modules (three drying rooms and three tempering sections), air ducts for fresh and exhaust air, four heat exchangers (one as a main heater and three as a reheaters), five fans (one for fresh air and four for exhaust air), two augers (filling auger and unloading auger), and inlet air measuring duct.
For the planned tests, three interventions were made at the dryer: 1) the duct after the heat exchanger was divided in three separate canals, and every one fitted up with a reheater, 2) the modules were supplied with sampling tubes, and 3) the fresh air entrance was completed with a measuring duct.

Introducing a single reheater for every drying room, means possibility for local temperature regulation, and therefore realization of multi-thermal zone drying system.

Sampling tube is an instrument for random sampling of rice during the drying process. The sampling tube uses a metal tube-in-tube construction with a spatial top which allows to be opened for sample taking.

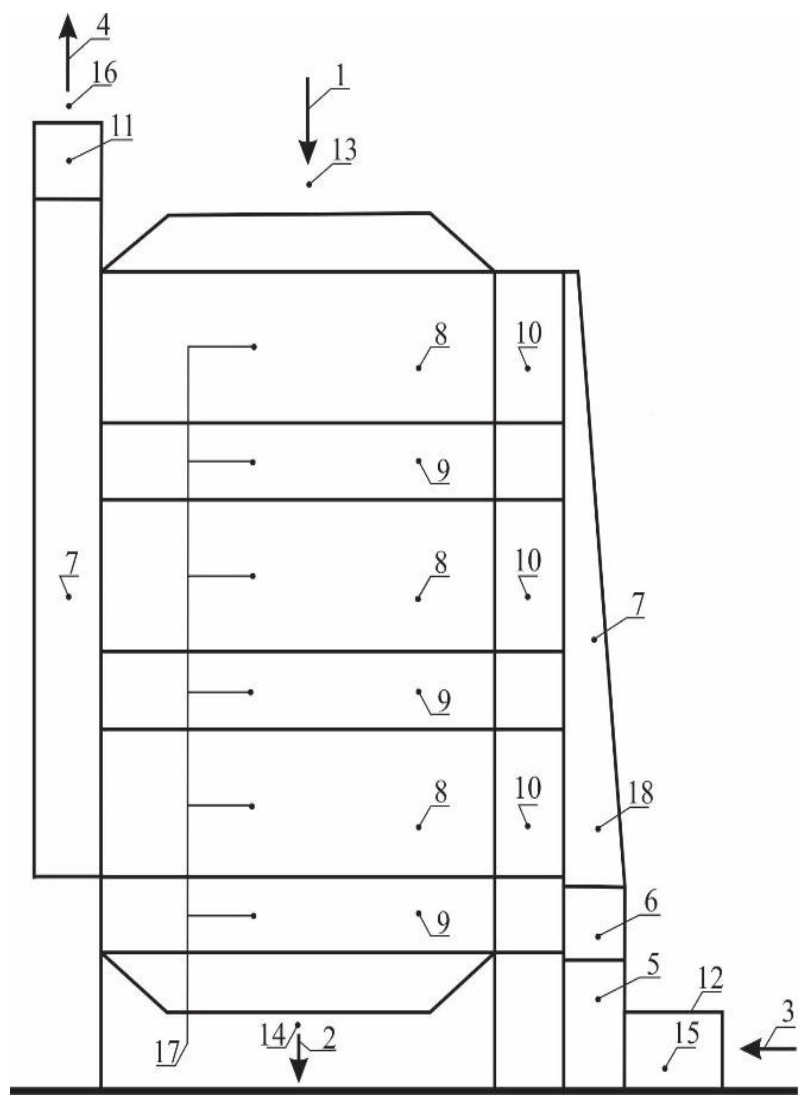

Fig. 1. Mixed-flow grain dryer

Dryer positions: 1) Grain inlet, 2) Grain outlet, 3) Air inlet, 4) Air outlet, 5) Fan, 6) Heater, 7) Air duct, 8) Drying room, 9) Tempering section, 10) Reheater, 11) Fan, 12) Measuring duct. Measuring points: 13) Initial moisture content, 14) Final moisture content, 15) Inlet air conditions and flow, 16) Outlet air conditions, 17) Grain moisture content,

18) Hot air conditions

The air flow measuring duct is added to the dryer to provide conditions for air flow measuring with standard hand-held Pitot-tube, in conjunction with a micromanometer. 
The wet rice flows gravitationally from the filling auger to the unloading auger. The heated air enters the drying room from open-bottomed horizontal intake ducts and flows through the rice to the surrounding exhaust ducts.

From the filling auger the wet grain enters in the first drying room where it encounters the hot air. The mutual flow of the rice and the air, in the drying room of a mixed-flow dryer, is combination of cross-flow, concurrent-flow and counter-flow. This kind of flow provides well distribution of heat in the grain mass. The result is dried grain with small variation in moisture content through the dryer, stepwise decrease of the moisture content and kernels temperature that is never approaching the maximum temperature of the drying air. During the stay in the drying room, air and grain temperatures equilibrate, while kernels continue to lose moisture.

The next step of the grain treatment occurs in the tempering section. In this phase, although there is no hot airflow, the drying process continues and grain moisture content is slightly decreasing.

After three times repeating of the heating and tempering process, dried rice is ready for the unloading auger.

Fresh air from the atmosphere is moved through the dryer by a fan, heated in the main heater, reheated in the reheaters and than distributed in the three drying rooms.

The fan for fresh air is centrifugal type and duct-connected with the heat exchanger. Outdoor air is heated in the heat exchanger. The heat exchanger is composed of several heating coil sections assembled into a bank. Hot water is used as a heating medium. The construction of the used reheaters is the same. They provide additional heating of the air before it enters in every drying room and also the possibility to use the drying rooms as elements of multi-thermal zone drying system. Four axial fans, for exhaust air, help the air to overcome the flow resistance in the drying room.

In order to control the drying conditions, and the behavior of a drying system at different heat flow intensities, necessary measurements were realized. All three participants in the drying process: drying medium, dried product and dryer were under continuous observation.

The state of the drying medium was monitored by measurement of air temperature, air relative humidity and air flow. The following instruments were used: thermometers, hygrometers, psychrometers and anemometers. The state of the dried product was observed by measurement of the moisture content and temperature. The initial, internal and final moisture content of paddy was inspected by taking representative samples in the filling auger, in every module and in the unloading auger. Rice moisture content was controlled by taking samples and their examination in laboratory, by direct method for moisture content determination, with automatic infrared moisture meter. The desirable final moisture content was reached at three levels, depending on intended rice use: for sale, for one year storage and for five years storage. The dryer function was regulated by an electrical command cabinet.

\section{RESULTS AND DISCUSSION}

The results of the applied Pitot-tube traverse method indicated that the fresh air rates are in the range of $35000-42000 \mathrm{~m}^{3} / \mathrm{h}$, with nominal value of $38000 \mathrm{~m}^{3} / \mathrm{h}$.

For the period of the research, conducted in October and November when the dryer always worked during daytime, inlet air state was in the interval: dry bulb temperature 10 to $25^{\circ} \mathrm{C}$, wet bulb temperature 5 to $21^{\circ} \mathrm{C}$, relative humidity 30 to $70 \%$ and specific enthalpy 16 to $65 \mathrm{~kJ} / \mathrm{kg}$.

In the main heater, air temperature has reached the level of $35^{\circ} \mathrm{C}$, while in the reheaters up to $45^{\circ} \mathrm{C}$. Test results showed that hot air temperature can be slightly higher in the first drying room, since paddy is still cool and has relatively high moisture content. The air temperatures of 40 to $42{ }^{\circ} \mathrm{C}$ were used in the first drying room. Tests conducted in order to find the maximum hot air temperature that can be tolerated, without reduction of the quality characteristics of rice, confirmed the temperature value of $44{ }^{\circ} \mathrm{C}$. Unbroken rice kernels or head rice, preferred for human food, were at suitable level only in the drying processes in which the grain temperature never surpassed $38^{\circ} \mathrm{C}$.

Nominal capacity of the dryer, mechanically regulated by unloading auger, was $2000 \mathrm{~kg} / \mathrm{h}$ grain.

The collected measurement results for the change of grain moisture content in the drying room, are summarized as drying curves. One example of drying curve, for locally grown paddy variety Monticelli is presented in Figure 2. The conditions were the following: initial moisture content, wet basis, $22 \%$, final moisture content, wet basis, $10 \%$, temperature in the first reheater $42^{\circ} \mathrm{C}$, temperature in the second reheater $40^{\circ} \mathrm{C}$ and the third reheater was disconnected. 


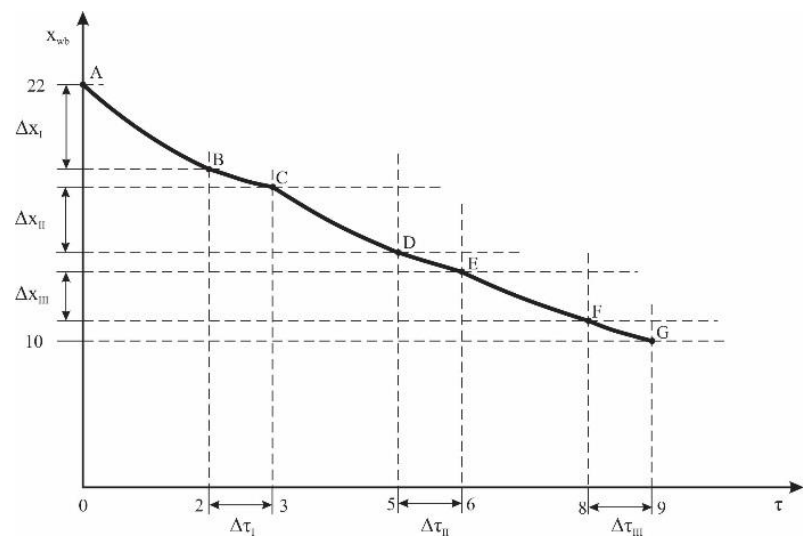

Fig. 2. Drying curve

The part $\mathrm{AB}$ illustrates the decrease of moisture content in the first drying room. In the next tempering section, there is no hot air and the moisture content is nearly unchanged. However, minimal grain drying is registered mainly as a result of the heat amount accumulated in the grain mass and metal construction of the tempering section. The part BC, shown in Figure 2, indicates the grain moisture content behaviour. There is a decrease of moisture content in the next two drying rooms, $\Delta \mathrm{x}_{\mathrm{I}}$ $>\Delta \mathrm{x}_{\text {II }}>\Delta \mathrm{x}_{\text {III. }}$ The retention time was equal, $\Delta \tau_{\mathrm{I}}=$ $\Delta \tau_{\mathrm{II}}=\Delta \tau_{\mathrm{III}}$

Paddy moisture content, wet basis, in the filling auger was 18 to $26 \%$, and entrance temperature of kernels was 10 to $25{ }^{\circ} \mathrm{C}$. Grain outlet moisture content, wet basis, was 8 to $12 \%$. Grain outlet temperature was up to $30^{\circ} \mathrm{C}$.

\section{CONCLUSIONS}

The conducted quality control of paddy processed in three-thermal zone drying system, using successive tempering, showed strong advantages of the applied slow drying process. The drying conditions: 2 to 2,6 hours grain stay in every drying room, with intermittent tempering of 1 to 1,3 hours, at hot air temperatures of up to $42{ }^{\circ} \mathrm{C}$ in the first drying room, up to $38^{\circ} \mathrm{C}$ in the second drying room and up to $34{ }^{\circ} \mathrm{C}$ in the third drying room, were selected as correct. Furthermore, the above described drying conditions offer minimum head yield loss.

The measured quantities of moisture content change are elaborated in the form of drying curves.

\section{REFERENCES}

[1] ASHRAE (American Society of Heating, Refrigerating and Air-Conditioning Engineers): Drying and Storing Selected Farm Crops, Handbook HVAC Applications, Atlanta, USA, 2011.

[2] Brooker, D. B., Bakker-Arkema, F. W., Hall, C. W.: Drying and Storage of Grain and Oilseeds, Van Nostrand Reinhold, New York, USA, 1992.

[3] Bigioi, D., Dobre, I.: The Importance of quality management for the agri-food products, Journal of Environmental Protection and Ecology, Vol. 8, No. 3, pp. 688-700 (2007).

[4] Custodio, M. C., Cuevas, R. P., Ynion, J., Laborte, A., G., Velasco, M. L., Demont, M.: Rice quality: How is it defined by consumers, industry, food scientists and geneticists?, Trends in Food Science \& Technology, Vol. 92, No. 10, pp. 122-137 (2019).

[5] USDA (United States Department of Agriculture), Federal Grain Inspection Service: United States Standards for Rice, Washington, D. C., USA, 2009.

[6] Schluterman, D. A., Siebenmorgen, T. J.: Relating rough rice moisture content reduction and tempering duration to head rice yield reduction, Transactions of the American Society of Agricultural and Biological Engineers, Vol. 50, No. 1, pp. 137-142 (2007).

[7] Aquerreta, J., Iguaz, A., Arroqui, C., Virseda, P.: Effect of high temperature intermittent drying and tempering on rough rice quality, Journal of Food Engineering, Vol. 80, No. 2, pp. 611-618 (2007).

[8] Ghasemi, A., Sadeghi, M., Mireei, S. A.: Multi-stage intermittent drying of rough rice in terms of tempering and stress cracking indices and moisture gradients interpretation, Drying Technology, Vol. 36, No. 1, pp. 109-117 (2017).

[9] State Statistical Office: Statistical Yearbook of the Republic of North Macedonia for 2019. Skopje, 2019. 